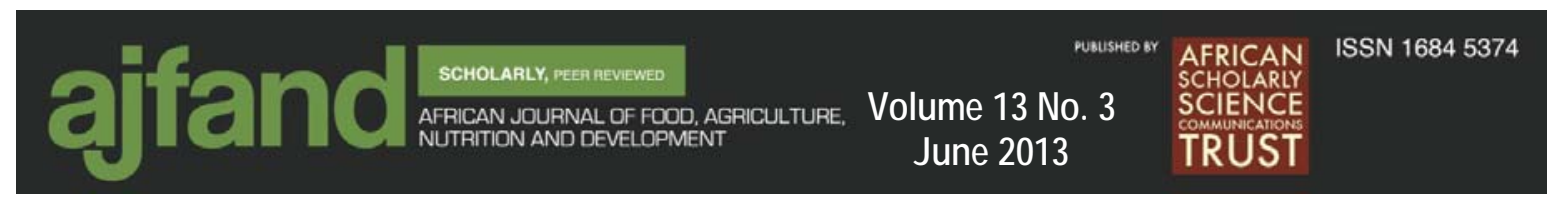

\title{
EFFECT OF PROCESSING ON THE QUALITY, COMPOSITION AND ANTIOXIDANT PROPERTIES OF Terminalia catappa (INDIAN ALMOND) SEED OIL
}

\section{Adu $\mathrm{OB}^{1 *}$, Omojufehinsi $\mathrm{M}^{1}$, Esanboro $\mathrm{MO}^{1}$, Abe $\mathrm{DA}^{1}$, Shofolahan $\mathrm{AO}^{1}$, Uzodinma $E^{1}$, Badmus $K^{1}$ and $O$ Martins ${ }^{2}$}

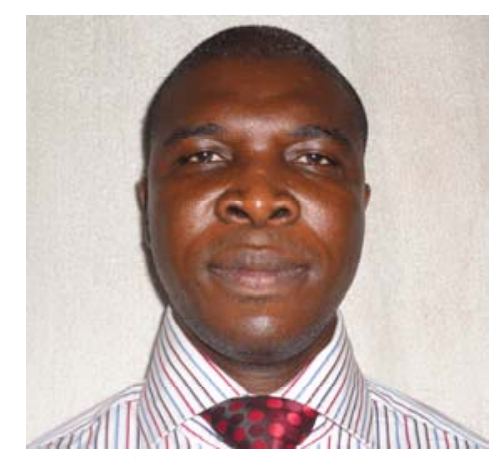

Oluwatosin Adu

${ }^{*}$ Corresponding author email: oluwatosin.adu@lasu.edu.ng

${ }^{1}$ Biochemistry Department, Lagos State University, Ojo PMB 001 LASU, Ojo, Lagos, Nigeria

${ }^{2}$ Drug Quality Control Unit, Lagos State Ministry of Health, Ikeja 


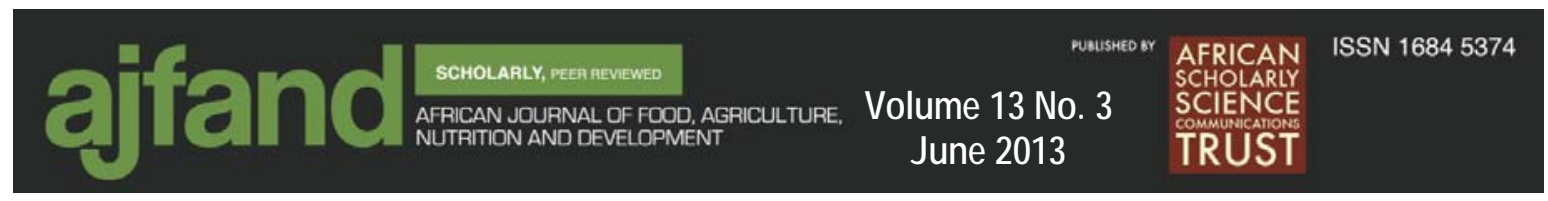

\section{ABSTRACT}

This study was aimed at extracting and purifying T. catappa seed oil with a view to investigating the effect of processing on the composition and antioxidant activity of the oil. Oil was extracted from the dried and roasted T. catappa seed and subjected to degumming and bleaching. The different processed oils were analysed for their fatty acid, phytosterols, and fat soluble vitamins composition. Antioxidant properties of the oils were also determined by measuring the Diphenylpicrylhydrazyl (DPPH) radical scavenging activity and inhibition of heat induced peroxidation. Roasting and processing caused a reduction in acid value, increased peroxide value, but had no effect on the iodine and saponification values of T. catappa oil. Palmitic acid was the most abundant saturated fatty acid $(42.466 \%)$ while oleic acid was the most abundant unsaturated fatty acid $(23.445 \%)$. Roasting significantly reduced fatty acid concentration of the oil, and bleaching of both unroasted and roasted oils increased the concentration of fatty acids except linoleic acid. Gamma-sitosterol and Betasitosterol were present in appreciable amounts only in the crude oils. Roasting increased Vitamins A and D concentrations but drastically reduced that of vitamin E. Degumming had no effect on the fat soluble vitamins of T. catappa oil, but bleaching significantly reduced the concentrations of all the vitamins. The DPPH radical scavenging activity of the seed oil was between $26.93 \pm 15.42 \%$ and $65.47 \pm 31.59 \%$. Refining increased the free radical scavenging activity of the unroasted oil, but did not affect the antioxidant activity of roasted oil. The capacity of the oil in preventing heat induced peroxidation was comparable to that of Butylated hydroxytoluene (BHT). Processing of the oil significantly increased its antioxidant activity. Loss of vitamin E did not affect the antioxidant activity of the oil. Thus, suggesting the presence of a heat stable antioxidant in the oil. This study indicated T. catappa seed oil to be potential pharmaceutical oil with good antioxidant characteristics.

Key words: Terminalia catappa, composition, antioxidant, processing, oil 


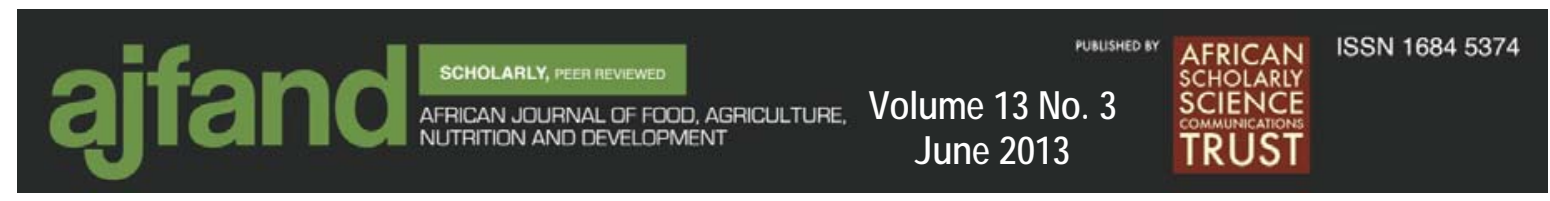

\section{INTRODUCTION}

Chemical screening programs for new oils have not only identified many plant species with new or unusual kinds of oils that will not only compete with the presently used vegetable oils (soybean, cottonseed, peanut and corn), but also those with high industrial promise[1]. Although purer oil is produced through purification steps, oil may become less stable during purification and refining. Oxidative stability as well as, triglyceride and fatty acid composition of oils are affected during these processes. The stability of some oils such as soybean oil is dependent on the presence of minor components including tocopherols, metal ions and phospholipids, which are partly removed during processing [2]. During bleaching, highly acidic activated clay can react with the oil and cause an undesirable dehydration reaction, discolouration and contribute to off-flavours development [3]. Oil processing steps that involve high temperatures can also affect the colour and flavour (aroma) of oils [4].

Terminalia catappa L. (Indian almond) is an underutilized crop which belongs to a group of nuts with hard shelled seeds enclosing a single edible kernel [5]. The plant, also called Tropical almond, is a large, spreading tree now distributed throughout the tropics in coastal environments. The seeds are often of small size and difficult to extract and these factors may have contributed to its lack of use in many areas. The sun-dried kernel yield 38-54\% of a bland, yellow oil that is edible but becomes turbid on standing [6]. The oil is used for cooking in some parts of South America and the nuts may be consumed fresh after extraction from the shell or preserved by drying or smoking and consumed up to a year later. Indian almond is rich in vitamin E and high in unsaturated fat [7]. Other parts of the plant such as bark, leaves, fruit shell, roots and trunks are used for medicinal and other non- food purposes [6].

This work was intended to determine the effect of processing of T. catappa seed on the composition and antioxidant properties of the oil.

\section{MATERIALS AND METHODS}

Collection of samples: Ripe T. catappa fruits were collected from various locations within Lagos metropolis between November and March. The outer flesh was manually removed with a scarpel and the hard-shelled nuts were sun-dried for 7 days. The kernels were extracted from the nut by manually breaking the dried shells with a hammer.

Preparation of dried seed: A $673.5 \mathrm{~g}$ portion of seed was dried in an oven (Gallenkamp, model 300 plus) at $125^{\circ} \mathrm{C}$ for $25 \mathrm{~min}$. The dried seeds were then allowed to cool, milled in a blender (Kenito, model, 300B) and weighed.

Preparation of roasted seed: A $660.2 \mathrm{~g}$ portion of seed was transferred into a stainless steel frying pan and roasted over a smokeless flame for $20 \mathrm{~min}$. After cooling, the roasted sample was then milled with blender and weighed.

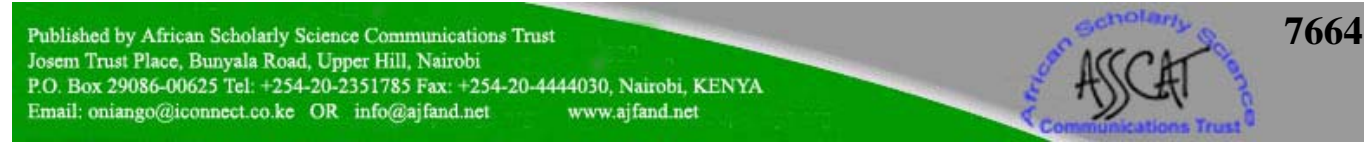




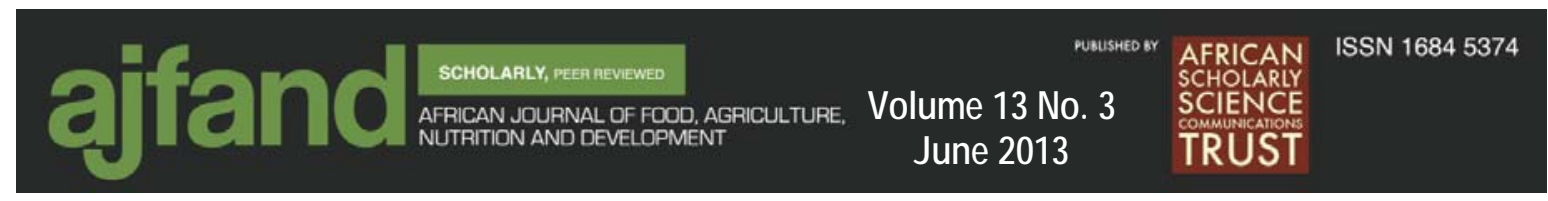

Extraction and purification of oil: The oil was extracted with petroleum ether by soxhlet extraction. Extraction was carried out for $6 \mathrm{hrs}$ in two batches (330g each) for both dried and roasted samples. Purification was done according to the method of Ogunsua and Badifu [8]. Two millilitres of distilled water was added to the crude Indian almond oil and heated at $70^{\circ} \mathrm{C}$ in a water bath for $30 \mathrm{~min}$. A $0.07 \mathrm{ml}$ of acetic anhydride was added and the mixture was stirred for $30 \mathrm{~min}$ at $70^{\circ} \mathrm{C}$ and thereafter cooled. The sample was then centrifuged at 2000rpm for $30 \mathrm{~min}$ and the supernatant decanted to obtain the degummed oil. To the degummed oil was added $7.55 \mathrm{~g}$ of $1 \mathrm{M}$ $\mathrm{KOH}$, and the mixture was stirred for $10 \mathrm{~min}$ at $25^{\circ} \mathrm{C}$ with a Stuart magnetic stirrer (model 8186) after which it was heated for $45 \mathrm{~min}$ at $80^{\circ} \mathrm{C}$ to coagulate the soap. This was further centrifuged at $2000 \mathrm{rpm}$ for $20 \mathrm{~min}$ in a Heraeus sepatech centrifuge. The oil was then washed with $80 \mathrm{ml}$ of distilled water by shaking the mixture vigorously in a separating funnel and allowing it to stand for $15 \mathrm{~min}$. The lower aqueous layer was then separated and discarded. The oils obtained from the dried and roasted samples were labeled "degummed".

Bleaching of purified oil: To the degummed oil, $0.56 \mathrm{~g}$ of fuller's earth was added and the mixture heated for $10 \mathrm{~min}$ at $100^{\circ} \mathrm{C}$. The mixture was then filtered under vacuum with a Whatman No 1 filter paper. Steam was passed into the bleached oil for $1 \mathrm{hr}$ and the oil was dried in an oven (Gallenkanp model, 300 plus) at $80^{\circ} \mathrm{C}$ for 30 min. Oils obtained from this process were labeled "bleached".

Characterisation of T. catappa oil: Acid, peroxide, iodine and saponification values of the oil samples were determined according to the AOAC method [9].

Fatty acid analysis: Quantitative determination of fatty acids in T. catappa oil samples was done according to the method of Metcalfe and Schmitz [10]. Oil samples $(0.187-0.22 \mathrm{~g})$ were saponified with $4.0 \mathrm{ml}$ of $0.5 \mathrm{M}$ methanolic $\mathrm{KOH}$. The fatty acids were converted to methyl esters, which were then analysed with Agilent GC-6890 and MSD-5973 Gas chromatography-mass spectrophotometry (GC-MS) equipment. $0.5 \mathrm{ml}$ of sample was passed through HP-1 column (A30 x $0.25 \mathrm{~mm} \times 0.25 \mu \mathrm{m})$ under the following conditions: Carrier gas, helium; initial temperature, $100^{\circ} \mathrm{C}$; temperature programmed at $10^{\circ} \mathrm{C} / \mathrm{min}$; final temperature, $250^{\circ} \mathrm{C}$; injector temperature, $250^{\circ} \mathrm{C}$; Detector temperature, $300^{\circ} \mathrm{C}$; run time, $32 \mathrm{sec}$.

Determination of fat soluble vitamins: Fat soluble vitamins were determined according to the method of Schumann et al [11]. T. catappa seed oil was diluted with ethanol in the ratio 1:50. A $1 \mathrm{ml}$ aliquot of sample was injected into an Agilent (1100 series) HPLC system. Reversed-phase chromatography was used with two solvents as mobile phases; methanol- water (99:5, v/v) under the following conditions; Column, Zorbax XDB-CB $(150 \times 4.6 \mathrm{~mm} \times 5 \mu \mathrm{m})$; wavelength $210 \mathrm{~nm}$; temperature, $35^{\circ} \mathrm{C}$; flow rate, $1.0 \mathrm{ml} / \mathrm{min}$. For standards preparation, individual stock standard solutions of each vitamin were mixed and prepared by mass in ethanol to provide a concentration of

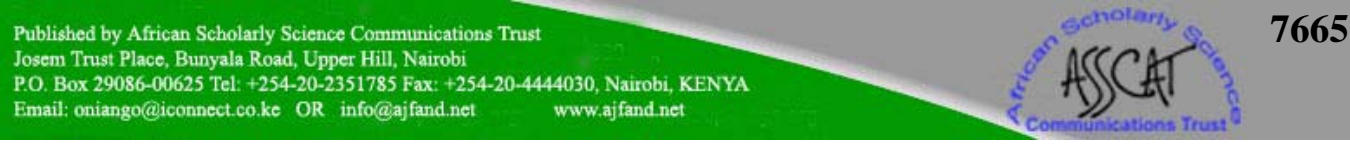




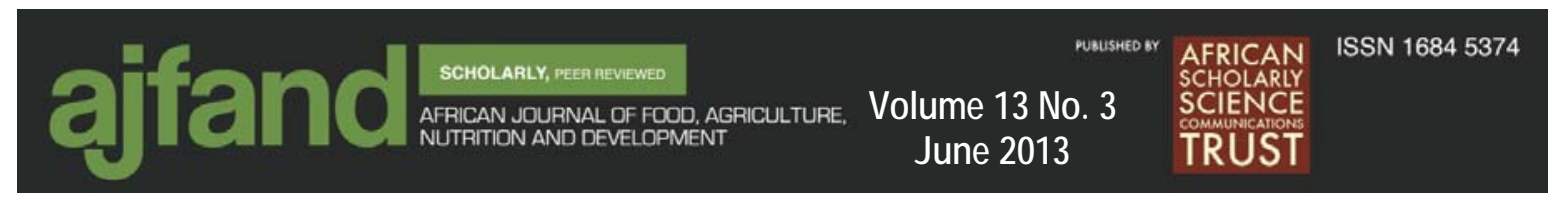

$2.5-100 \mu \mathrm{g} / \mathrm{ml}$ for the fat soluble vitamins, retinol, cholecalceferol, and tocopherol (Sigma, St. Loius, MO, USA).

Determination of Diphenylpicrylhydrazyl (DPPH) radical scavenging activity: The DPPH scavenging activity of T. catappa seed oil was determined according to the method of Burits and Bucar [12]. DPPH solution $(0.5 \mathrm{mM})$ in methanol was prepared and $1 \mathrm{ml}$ of this solution was mixed with $3 \mathrm{ml}$ of the sample solution in ethanol (1$5 \mathrm{mg} / \mathrm{ml}$ ). Butylated hydroxyl toluene (BHT) was used as a positive control. Percentage DPPH scavenging activity was calculated as:

$\%$ DPPH radical scavenging activity $=$

[Control absorbance - Sample absorbance] X 100

Control absorbance

The control sample contained $1 \mathrm{ml}$ of DPPH solution and $3 \mathrm{ml}$ ethanol.

Auto oxidation of sunflower oil: The antioxidant capacity of $T$. catappa oil in preventing auto oxidation in sunflower oil was determined. Oven accelerated oxidation of sunflower oil containing 200ppm of T. catappa oil was carried out [13]. Green tea extract and butylated hydroxytoluene (BHT) were used as standard antioxidants. A $0.0005 \mathrm{~g}$ portion of the crude, purified and bleached samples of the roasted and unroasted seeds were introduced into $2.5 \mathrm{ml}$ of sunflower oil. Thermal oxidation was induced in an oven (Gallenkamp 300 plus series) at $65^{\circ} \mathrm{C}$ for 5 hours.

Determination of peroxide value: One gram of the induced oil sample was weighed into a $250 \mathrm{ml}$ conical flask and $5 \mathrm{ml}$ of acetic acid and chloroform (3:2) was added and shaken until the oil completely dissolved. Then $0.1 \mathrm{ml}$ of potassium iodide was added and shaken for $1 \mathrm{~min}$. Six milliliters of distilled water and $0.1 \mathrm{ml}$ of $1 \%$ starch solution was also added. Then $0.01 \mathrm{M}$ of sodium thiosulphate was titrated against the mixture until the blue-black colouration disappeared completely. A blank test without the oil sample was also carried out.

Statistical analysis: All analyses were carried out in triplicates and data expressed as mean \pm standard deviation. Means were compared using Univariate analysis of variance and Tukey's highly significant difference test was used for post hoc analyses, using the SPSS (version 11) software.

\section{RESULTS}

The yield of crude oil (Table 1) extracted from roasted T. catappa seed (29.1 $\pm 5.4 \%)$ was not different from that of the unroasted seed $(30.4 \pm 5.2 \%)$.

The characteristic of the crude and processed oils from $T$. catappa seed is presented in Table 2. The acid value of the oils, was in the order, $0.35 \pm 0.07$ in roasted degummed $<$ unroasted degummed $<$ unroasted bleached $<$ Roasted bleached $<$ Roasted crude $<$ 


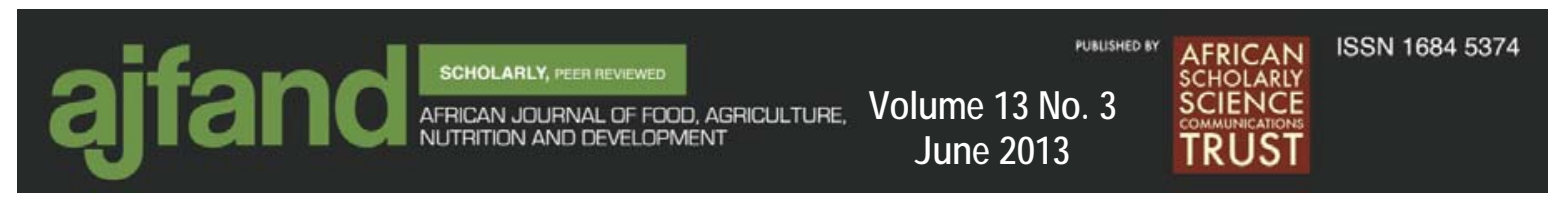

Unroasted crude $(2.73 \pm 0.07)$. Peroxide value of the oils was in the order $3.90 \pm 1.70$ $\mathrm{meq} / \mathrm{kg}$ in unroasted crude $<$ Unroasted degummed $<$ Unroasted bleached $<$ Roasted degummed $<$ Roasted crude $<$ Roasted bleached $(15.90 \pm 0.70 \mathrm{meq} / \mathrm{Kg})$. In both roasted and unroasted seed, iodine value of the bleached oil was significantly higher $(\mathrm{p}<$ 0.05 ) than that of the crude. Saponification value of T. catappa oil was in the order $336.53 \pm 13.97 \mathrm{mg} \mathrm{KOH} / \mathrm{g}$ in Roasted bleached < Unroasted bleached < Unroasted degummed $<$ Roasted degummed $<$ Roasted crude $<$ Unroasted crude $(396.21 \pm 1.56 \mathrm{mg} \mathrm{KOH} / \mathrm{g}$ ). There was no difference in the saponification value between the roasted and unroasted crude oils. Bleached oils had significantly lower saponification values $(p<0.05)$ compared to the crude.

The fatty acid profile showed a very simple pattern consisting of Hexadecanoic acid, Tetradecanoic acid, Octadecanoic acid, 9-Hexadecenoic acid, 9-Octadecenoic acid, 9,12-Octadienoic acid (Table 3). Hexadecanoic (palmitic acid) was the major fatty acid in T. catappa oil (4.58\% - 42.47\%). Unroasted T. catappa seed oil had a higher concentration of Tetradecanoic (myristic) acid (17.07\% - 36.14\%). 9-Octadecenoic (oleic acid) was the most abundant unsaturated fatty acid in T. catappa oil and bleached oil had the highest concentration in both roasted $(20.94 \%)$ and unroasted $(23.45 \%)$ seed. The concentration of linoleic acid decreased in the unroasted seed oil from $6.27 \%$ in crude to $4.86 \%$ in bleached oil; but increased in the roasted seed oil as purification progressed. Linoleic acid was not detected in roasted crude oil.

The phytosterol detected in T. catappa seed oil were mainly Gamma $(\gamma)$ sitosterol and beta $(\beta)$ sitosterol (Table 4). The concentration of the sterols decreased as purification progressed. Phytosterol concentration decreased from $25.60 \%$ in the unroasted crude to $22.29 \%$ in the unroasted degummed, and from $11.66 \%$ in the roasted crude to $0.61 \%$ in the roasted degummed oil. Phytosterols were not detected in the bleached T. catappa oil.

Fat soluble vitamin composition (Vit A, D and E) of T. catappa seed oil are shown in Table 5. Vitamin A was the major fat soluble vitamin in oils from both unroasted and roasted seed. Concentration of Vitamin A was significantly higher $(p<0.05)$ in the roasted crude oil compared to other oils. Vitamin D was highest in the roasted crude $(7.19 \pm 2.21 \%)$ but was not detected in the unroasted crude and degummed $T$. catappa oil. Unroasted crude oil had the highest Vitamin E concentration (4.38 \pm $0.88 \%)$. This concentration was significantly $(\mathrm{p}<0.05)$ higher compared to other $T$. catappa oil.

The DPPH radical scavenging activity of T. catappa oil (Table 6) was significantly lower $(\mathrm{p}<0.05)$ than that of Butylated hyroxytoluene (BHT). The DPPH scavenging activity of unroasted crude oil $(26.93 \pm \mathrm{I} 5.42 \%)$ was significantly lower $(\mathrm{p}>0.05)$ than all the other oil samples. The free radical scavenging activity of the roasted seed oil decreased as purification progressed.

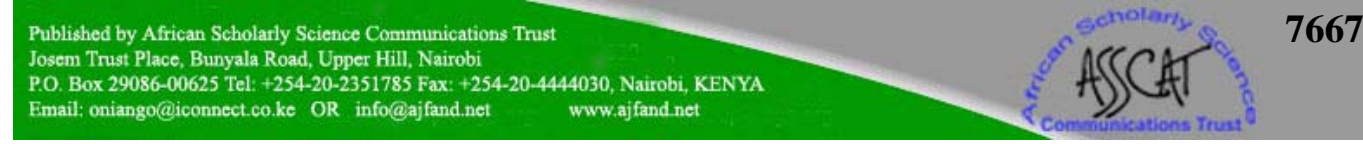




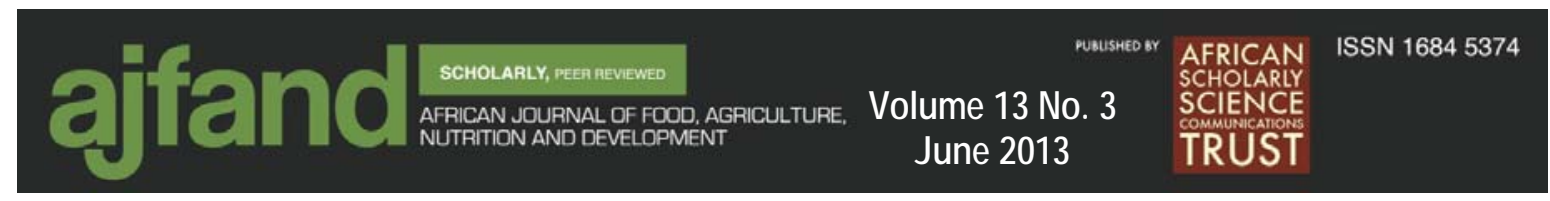

The DPPH radical scavenging activity of $T$. catappa seed oil increased with increasing concentration of the oil (Figure 1). The roasted oil had the highest DPPH radical scavenging activity at the concentration of $5 \mathrm{mg} / \mathrm{ml}$ followed by the unroasted degummed, roasted bleached and unroasted bleached oil. The unroasted crude oil had the lowest scavenging activity even at the highest concentration.
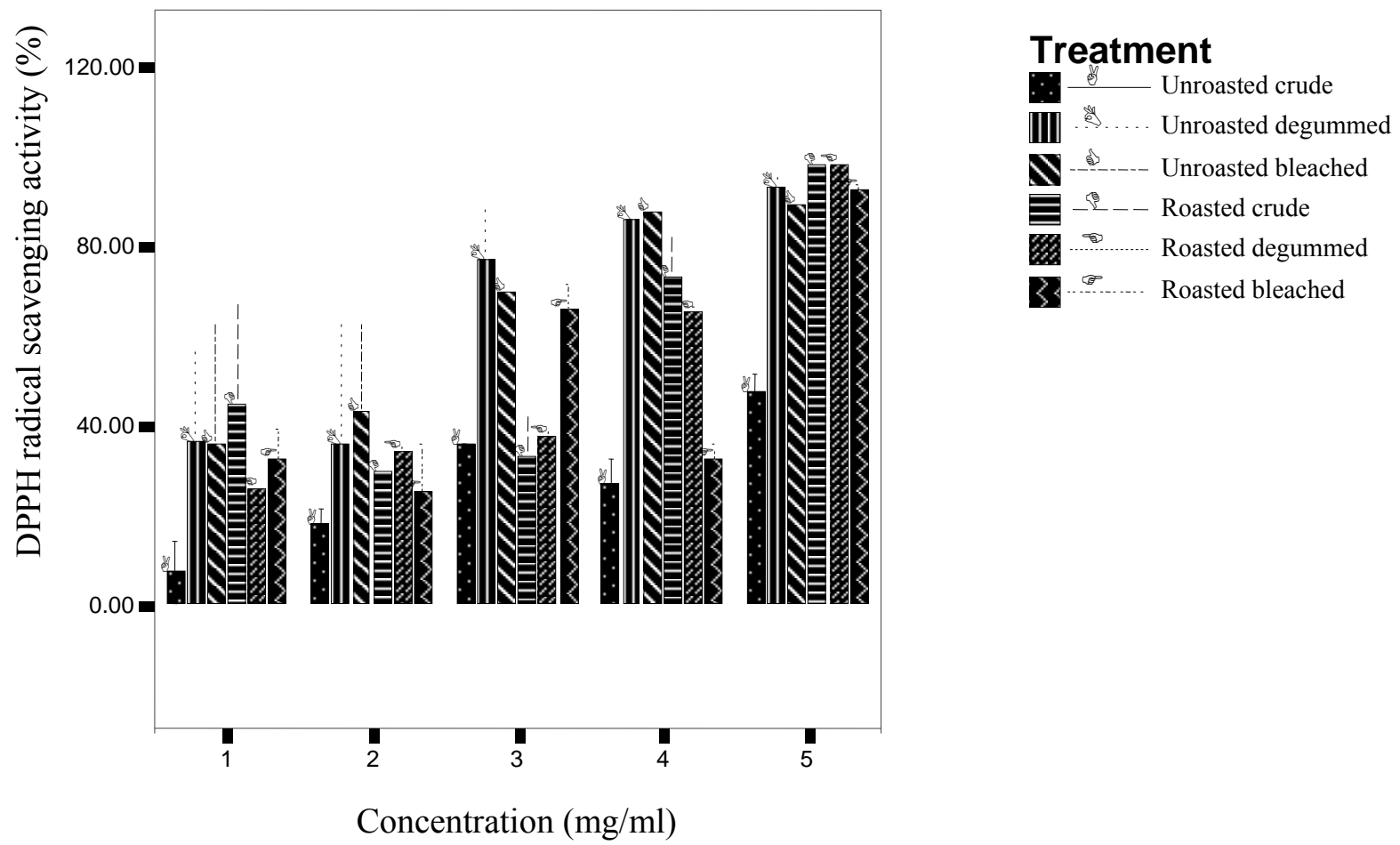

Figure 1: DPPH radical scavenging activity of T.catappa seed oil as a function of concentration

Peroxide value of sunflower oil after $5 \mathrm{hrs}$ of heat induced oxidation with and without T. catappa oil is presented in Table 7 . Inhibition of oxidation was in the order unroasted bleached $<$ roasted crude $<$ roasted bleached $<$ unroasted crude $<$ unroasted degummed $<$ roasted degummed $<$ BHT $<$ GTE.

\section{DISCUSSION}

The percentage yield of T. catappa seed oil was $34.1 \%$ for the unroasted seed oil and $32.9 \%$ for the roasted seed oil as shown in Table 1 . This compared favorably with other oil bearing seeds such as palm kernel (40\%), peanuts (49\%), cotton seed (36\%) and soybean $(20 \%)$ [14]. The values reported in the present study were, however, lower than those reported by Omeje et al. [15]. The lower yield may be attributed to 


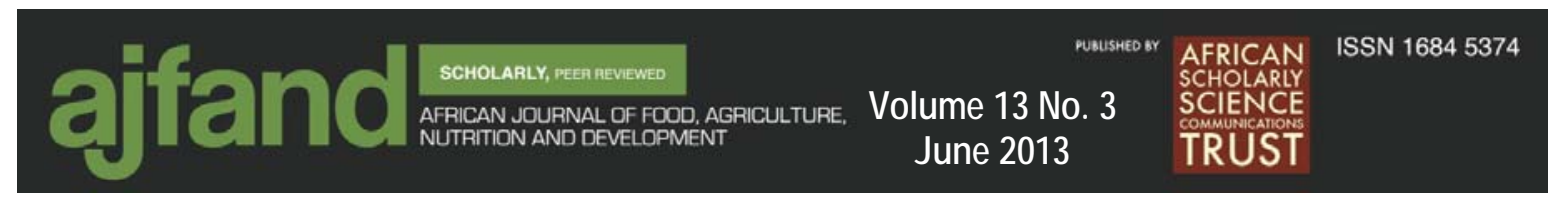

the duration of oil extraction (6hrs). Omeje et al. [15] employed an extraction period of $16 \mathrm{hrs}$.

The fatty acid composition of oil is its most useful chemical feature. Many of the chemical tests for oil identity or purity can be related to the fatty acid content of the oil [16]. Terminalia catappa seed oil had higher amount of saturated fatty acid than unsaturated fatty acid. Ajayi et al. [17] reported a higher concentration of unsaturated fatty acids in T. catappa oil. Palmitic, myristic, and stearic acids were the main saturated fatty acids while palmitoleic, oleic and linoleic acids were the major unsaturated fatty acids. Palmitoleic and oleic acid are the major monounsaturated fatty acid (MUFA). Studies have demonstrated that MUFA are better contributors to plasma cholesterol lowering effects [17]. The presence of monounsaturated fatty acid can counteract the effect of the saturated fatty acid and the seed oil can be of nutritional benefit. The predominant saturated fatty acid was palmitic acid while the predominant unsaturated fatty acid was oleic acid. This is in agreement with the result of Ajayi et al. [17] on T. catappa oil and that of Ajayi and Adesanwo [16] on Dacrodes edulis oil.

Essential fatty acids are useful in alleviating fatty acid syndrome and in preventing coronary heart disease [18]. The presence of linoleic acid, which is an essential fatty acid, makes T. catappa seed oil nutritionally valuable. Short chain fatty acid such as myristic acid was detected in T. catappa seed oil, but long chain fatty acids such as Arachidonic acid (C20:0), lignoceric (C24:0) and cerotic (C26:0) acid; Polyunsaturated fatty acids such as linolenic acid (C18:3) were not detected in $T$. catappa seed oil. This is in agreement with the result of Ajayi et al. [17].

Generally, processing has various effects on the fatty acid composition of the seed oils. Processing could result in oxidative deterioration of longer chain n-3 fatty acids such as linoleic acid [19]. When vegetable oil was heated, the level of free fatty acid increased through the hydrolysis of triglyceride, and there was accumulation of saturated short chain fatty acid [20]. During processing of T. catappa seed oil, there was a reduction in the concentration of fatty acid. Increase in temperature (roasting) reduced the concentration of all the fatty acids. In the unroasted seed oil, degumming resulted in the reduction of the fatty acid concentration. Thereafter, there was an increase during the bleaching process except for the linoleic acid whose concentration decreased from the crude to the bleached oil. In the roasted oil, degumming increased the fatty acid concentration of palmitic, myristic and linoleic acid while the reverse was observed for stearic, palmitoleic and oleic acid. The highest concentration of fatty acid was detected in the bleached oil except for linoleic acid in the unroasted seed oil. This indicated that bleaching increased the concentration of fatty acid and that linoleic acid seems very sensitive to processing.

Plant oils are particularly rich sources of phytosterols. Studies have shown that phytosterols such as beta-sitosterol may help normalize the function of T-helper lymphocytes and natural killer cells following stressful events [21]. Dietary

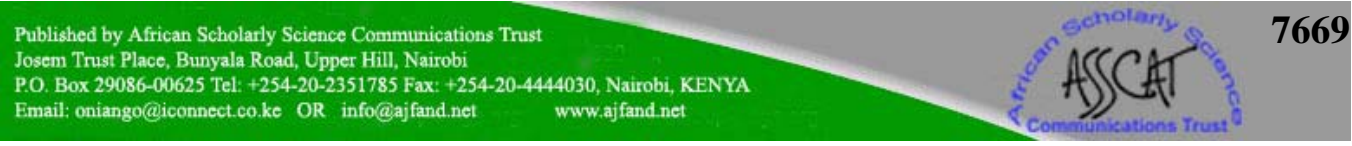


phytosterols are also able to lower serum cholesterol and slow the growth and spread of cancer cells [21]. Terminalia catappa seed oil contained equal amount of betasitosterol and gamma-sitosterol. Some loss of sterols by evaporation during high temperature processing is inevitable. However, the loss of sterols need not be severe if the processing conditions are well-chosen. Extreme conditions applied in model studies however do induce more drastic effects. Typical result obtained for soybean oil showed that after 2 hours at $300^{\circ} \mathrm{C}$ (a drastic treatment), the sterol almost completely disappeared whereas the reduction during physical refining at $240^{\circ} \mathrm{C}$ for 120 min was only about $15-20 \%$, the total refining losses (including pretreatment) were about $25-35 \%$ [22]. In this study, during roasting, the concentration of phytosterol decreased by $54 \%$. During degumming, there was also a reduction in the concentration of the sterols but the roasted oil was more affected (94\%). Bleaching caused complete loss of the sterols in T. catappa seed oil.

Vitamin A is affected drastically during processing. Thus, special processes for retention are being designed. Olive and sesame oils are used in the unrefined form [23]. Roasting of T. catappa seed increased Vitamin A concentration in its oil. However, further processing (degumming and bleaching), resulted in the reduction of the vitamin. While degumming only slightly reduced vitamin A concentration, bleaching drastically reduced it. In unroasted T. catappa Vitamin D was not present in the crude and degummed oil but was present in the bleached oil. Vitamin D was, however, present in all three roasted samples, but its concentration decreased as processing ensued. Vitamin $\mathrm{E}$ is an antioxidant molecule and its primary task is to prevent the damage caused by free radicals on tissues. This is achieved by donating a hydrogen atom to peroxide radical which results from the degradation of unsaturated lipids [24]. Increase in temperature resulted in thermal degradation of Vitamin $\mathrm{E}$ thus, a reduction of its concentration [25]. Terminalia. catappa seed oil had a high Vitamin E content, but roasting of the seed and purification of the oil caused significant losses of the Vitamin which may be due to oxidation.

Free radicals are highly reactive molecules with an unpaired electron and are produced by radiation or as by-product of metabolic processes. They initiate chain reactions which lead to disintegration of cell membranes and cell compounds, including lipids, proteins and nuclei acids. Beside damage to living cells, free radicals are the major cause of food deterioration through lipid oxidation which ultimately affect the organoleptic properties and edibility of foods. Hence, intervention of an antioxidant may have a therapeutic effect and also maintain the freshness of food product [26]. Diphenylpicrylhydrazyl (DPPH) is also considered as a good kinetic model for peroxyl radicals [27]. The DPPH radical scavenging activity of T. catappa oil was high but significantly $(\mathrm{p}<0.05)$ lower than that of BHT. This is in agreement with the result of Ramadan et al [28]. The effect on DPPH is indicative of the hydrogen donating ability of T. catappa seed oil [29]. Processing of the oil significantly increased its antioxidant activity in spite of the loss of vitamin E activity. This suggests the presence of a heat stable antioxidant in the oil which may be potentiated by processing in the absence of vitamin E. Omeje et al. [16] reported

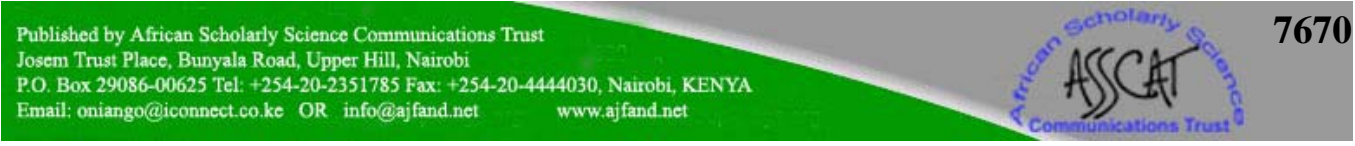




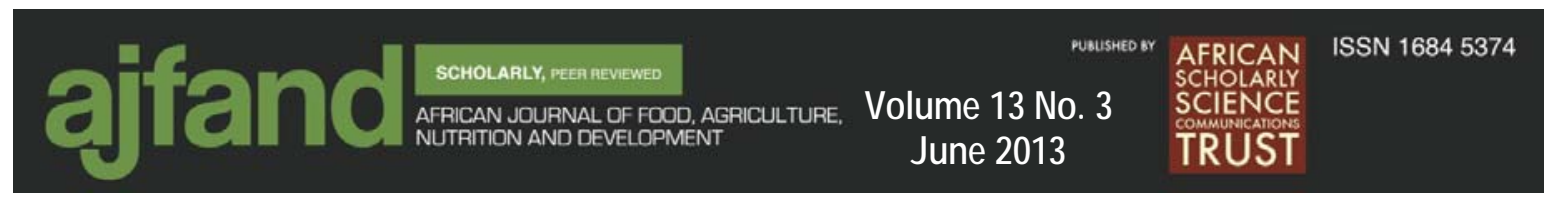

higher antioxidant activity of the refined oil of T. catappa and also suggested the presence of an in situ antioxidant.

During thermal autoxidation in the dark by overheating, radical autoxidation occurs when hydroperoxides and peroxides are breaking down and generating more free radicals to maintain the chain reaction. The peroxide value (PV) is a measure of the oxidation of triglyceride and any value less than $5 \mathrm{meq} / \mathrm{kg}$ shows no significant oxidation [30]. The double bond in fats and oils plays a role in autoxidation, thus, oils with a high degree of unsaturation are most suspectible to autoxidation. The antioxidant activity of roasted degummed oil was comparable to that of BHT and Green tea extract. Thus, T. catappa oil is effective in preventing heat induced peroxidation.

\section{CONCLUSION}

Physicochemical properties of T. catappa oil were stable during processing. The oil is rich in fat soluble vitamins, but bleaching of the oil resulted in drastic losses of these vitamins. Refining increased the free radical scavenging activity of the unroasted oil, and the capacity of the oil in preventing heat induced peroxidation was comparable to that of BHT. Processing of the oil significantly increased its antioxidant activity. Loss of vitamin E did not affect the antioxidant activity of the oil thus, suggesting the presence of a heat stable antioxidant in the oil. This study indicated T. catappa seed oil to be potential pharmaceutical oil with good antioxidant characteristics. 


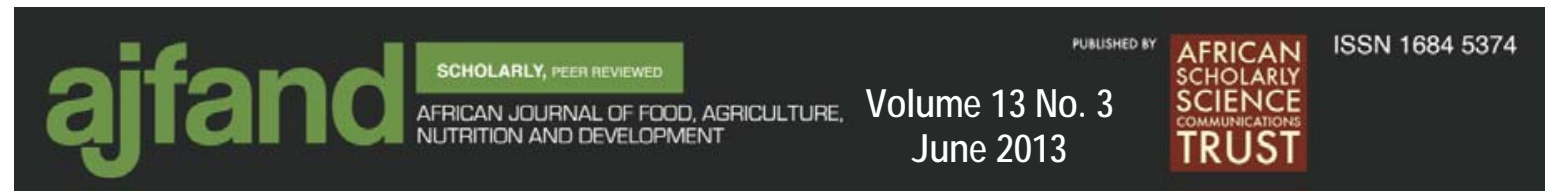

Table 1: Percentage yield of extracted T. catappa seed oil

\begin{tabular}{ccc}
\hline Parameter & $\begin{array}{c}\text { Unroasted T. catappa seed } \\
\text { (\%) }\end{array}$ & $\begin{array}{c}\text { Roasted T. catappa seed } \\
\text { (\%) }\end{array}$ \\
\hline Crude Oil & $30.4 \pm 5.2^{\mathrm{a}}$ & $29.1 \pm 5.4^{\mathrm{a}}$ \\
\hline
\end{tabular}

${ }^{a}$ Values with different superscript are significantly different at $\mathrm{p}<0.05$

Table 2: Characteristics of crude and processed $T$. catappa oil

\begin{tabular}{lllll}
\hline & $\begin{array}{l}\text { Acid } \\
\text { value }\end{array}$ & $\begin{array}{l}\text { Peroxide } \\
\text { value } \\
\text { (meq/kg) }\end{array}$ & $\begin{array}{l}\text { Iodine } \\
\text { value }\end{array}$ & $\begin{array}{l}\text { Saponification value } \\
\text { (mg KOH/g) }\end{array}$ \\
\hline Unroasted crude & $2.73 \pm 0.07$ & $3.90 \pm 1.70$ & $59.35 \pm 5.73$ & $396.21 \pm 1.56$ \\
Unroasted degummed & $0.42 \pm 0.00$ & $9.50 \pm 1.30$ & $58.85 \pm 0.71$ & $346.72 \pm 7.34$ \\
Unroasted bleached & $0.56 \pm 0.00$ & $13.8 \pm 0.40$ & $76.10 \pm 1.41$ & $345.14 \pm 3.50$ \\
Roasted crude & $1.61 \pm 0.35$ & $11.30 \pm 0.10$ & $52.00 \pm 6.08$ & $371.67 \pm 7.10$ \\
Roasted degummed & $0.35 \pm 0.07$ & $14.60 \pm 0.60$ & $48.45 \pm 1.77$ & $354.14 \pm 3.5$ \\
Roasted bleached & $0.63 \pm 0.07$ & $15.9 \pm 9.00$ & $76.10 \pm 0.00$ & $336.53 \pm 13.97$ \\
\hline
\end{tabular}




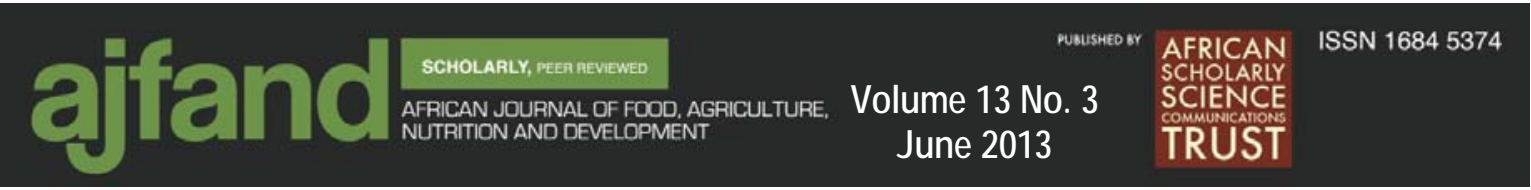

Table 3: Fatty acid composition of $T$. catappa seed oil

\begin{tabular}{|c|c|c|c|c|c|c|}
\hline \multirow[t]{2}{*}{ Fatty acid methyl esters } & \multicolumn{3}{|c|}{ Unroasted T. catappa seed oil (\%) } & \multicolumn{3}{|c|}{ Roasted T. catappa seed oil (\%) } \\
\hline & Crude & Degummed & Bleached & Crude & Degummed & Bleached \\
\hline $\begin{array}{l}\text { Tetradecanoic acid } \\
\text { (Myristic acid) C14:0 }\end{array}$ & 22.940 & 17.067 & 36.138 & 1.263 & 7.629 & - \\
\hline $\begin{array}{l}\text { Hexadecanoic acid } \\
\text { (Palmitic acid) C16:0 }\end{array}$ & 22.940 & 17.067 & 42.466 & 4.578 & 9.958 & 33.001 \\
\hline $\begin{array}{l}\text { Octadecanoic acid } \\
\text { (Stearic acid) } \quad \text { C18:0 }\end{array}$ & 3.002 & - & 4.975 & - & 2.391 & 5.985 \\
\hline $\begin{array}{l}\text { Total saturated } \\
\text { fatty acid }\end{array}$ & 48.882 & 36.104 & 83.579 & 7.104 & 18.622 & 38.986 \\
\hline $\begin{array}{l}\text { 9-Hexadecanoic acid } \\
\text { (Palmitoleicacid) C16:19}\end{array}$ & - & - & 23.445 & 7.072 & 0.952 & - \\
\hline $\begin{array}{l}\text { 9-Octadecanoic acid } \\
\text { (Oleic acid) C } 18: 1^{9}\end{array}$ & 13.449 & 12.587 & 23.445 & 7.072 & 4.336 & 20.937 \\
\hline $\begin{array}{l}\text { 9,12- Octadeienoic acid } \\
\text { (linoleic acid }\end{array}$ & 6.266 & 5.729 & 4.855 & - & 3.056 & 3.817 \\
\hline $\begin{array}{l}\text { Total unsaturated fatty } \\
\text { acid }\end{array}$ & 19.715 & 18.316 & 51.745 & 14.144 & 8.344 & 24.754 \\
\hline
\end{tabular}

Table 4: Phytosterol composition of T. catappa seed oil

\begin{tabular}{lcccccc}
\hline Phytosterol & \multicolumn{2}{c}{ Unroasted T. catappa seed oil (\%) } & \multicolumn{2}{c}{ Roasted T. catappa seed oil (\%) } \\
\hline & Crude & Degummed & Bleached & Crude & Degummed & Bleached \\
\hline Gamma-sitosterol & 25.603 & 22.289 & - & 11.657 & 0.609 & - \\
Beta-sitosterol & 25.603 & - & - & 11.657 & 0.609 & - \\
\hline
\end{tabular}




ajfand

Table 5: Fat soluble vitamin composition of T. catappa seed oil

\begin{tabular}{llll}
\hline \multicolumn{1}{c}{ Sample } & Vitamin A (\%) & Vitamin D (\%) & Vitamin E \%) \\
\hline Unroasted crude & $39.38 \pm 3.54^{\mathrm{b}}$ & $0.00 \pm 0.00^{\mathrm{a}}$ & $4.38 \pm 0.88^{\mathrm{a}}$ \\
Unroasted degummed & $35.63 \pm 20.33^{\mathrm{b}}$ & $0.00 \pm 0.00^{\mathrm{a}}$ & $2.81 \pm 0.44^{\mathrm{a}, \mathrm{b}}$ \\
Unroasted bleached & $7.50 \pm 0.00^{\mathrm{c}}$ & $5.00 \pm 0.00^{\mathrm{a}}$ & $0.63 \pm 0.00^{\mathrm{b}}$ \\
Roasted crude & $65.31 \pm 3.09^{\mathrm{a}}$ & $7.19 \pm 2.21^{\mathrm{a}}$ & $0.63 \pm 0.88^{\mathrm{b}}$ \\
Roasted degummed & $64.69 \pm 41.98^{\mathrm{a}}$ & $5.94 \pm 1.33^{\mathrm{a}}$ & $0.63 \pm 0.00^{\mathrm{b}}$ \\
Roasted bleached & $16.88 \pm 0.00^{\mathrm{c}}$ & $3.13 \pm 4.42^{\mathrm{a}}$ & $0.94 \pm 0.44^{\mathrm{b}}$ \\
\hline
\end{tabular}

Values with different superscript are significantly different at $\mathrm{P}<0.05$

Table 6: DPPH radical scavenging effect of $T$. catappa seed oil

\begin{tabular}{lc}
\hline T. catappa seed oil & DPPH radical scavenging activity (\%) \\
\hline Unroasted crude & $26.93 \pm \mathrm{I} 5.42^{\mathrm{a}}$ \\
Unroasted degummed & $65.47 \pm 31.59^{\mathrm{b}}$ \\
Unroasted bleached & $65.00 \pm 28.86^{\mathrm{b}}$ \\
Roasted crude & $55.64 \pm 31.25^{\mathrm{b}}$ \\
Roasted degummed & $52.04 \pm 27.89^{\mathrm{b}}$ \\
Roasted bleached & $49.50 \pm 28.00^{\mathrm{b}}$ \\
Control (BHT) & $100.00 \pm 0.00^{\mathrm{c}}$
\end{tabular}

Values with different superscript are significantly different at $\mathrm{P}<0.05$ 
Table 7: Peroxide value of sunflower oil after $5 \mathrm{hrs}$ of induction

\section{T. catappa seed oil}

Unroasted crude

Unroasted degummed

Unroasted bleached

Roasted crude

Roasted degummed

Roasted bleached

Green tea extract

BHT

control

\section{Peroxide value $(\mathrm{meq} / \mathrm{kg})$}

$$
\begin{aligned}
& 6.00 \pm 0.00^{\mathrm{ab}} \\
& 6.00 \pm 0.00^{\mathrm{ab}} \\
& 8.50 \pm 0.71^{\mathrm{b}} \\
& 8.50 \pm 0.71^{\mathrm{b}} \\
& 5.00 \pm 1.41^{\mathrm{a}} \\
& 7.50 \pm 0.71^{\mathrm{ab}} \\
& 4.50 \pm 0.71^{\mathrm{a}} \\
& 5.00 \pm 1.41^{\mathrm{a}} \\
& 8.50 \pm 0.71^{\mathrm{b}}
\end{aligned}
$$

The peroxide values were obtained after $5 \mathrm{hrs}$ of thermal oxidation of sunflower oil with or without $T$. catappa oil. Value with different superscript are significantly different at $\mathrm{P}<0.05$ 


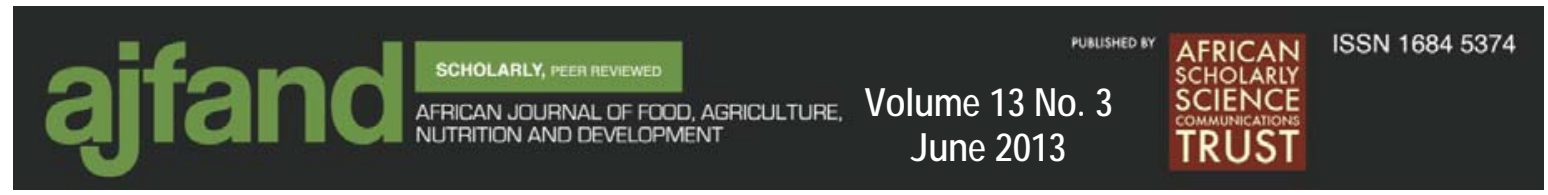

\section{REFERENCES}

1. Adebisi M Fatty acid composition of seed oil of some members of meliaceae and combreteceae families. Journal of Science. 1985; 62:529.

2. Gordon MH and IA Rahman Effect of processing on the composition and oxidative stability of coconut oil. J Am Oil Chem Soc. 1991; 68:574-576.

3. Stauffer CE Fats and Oils. Eagan Press, St Paul, Minnesota, 1996.

4. Hamm W Vegetable Oils. In, Kirk-Othmer, Encyclopedia of Chemical Technology, 3rd Edition, Wiley-Interscience, 1983.

5. Othmer M Vegetable oils. New Encylopedia of Chemical Technology, 1976; 19:348-359.

6. Thomson LAJ and B Evans Species Profiles for Pacific Island Agroforestry. [Online], http://www.traditionaltree.org.pdf. 2006. Accessed 15/06/09

7. Ziller S Food Fats and Oils. $7^{\text {th }}$ ed. Institute of Shortening and Edible Oils, Washington DC, 1994

8. Ogunsua, AO and GIO Badifu Stability of purified melon seed oil by solvent extraction. Journal of Food Science, 1989; 54: 71.

9. AOAC. Official Methods of Analysis 16 $6^{\text {th }}$ edn. Arlington, VA. 1995.

10. Metcalfe LD and AA Schmitz The rapid preparation of fatty acid ester for gas chromatographic analysis, Annals of Chemistry, 1961; 33: 363.

11. Schumann K, Classen HG, Hages M, Priz-Langenohl R, Pietrizik K and HK Biesaki Bioavailability of oral vitamins, minerals and trace element in perspective. Areneimittel for Forschung, 1997; 47(4): 369-380.

12. Burits $\mathbf{M}$ and F Bucar Antioxidant activity of Nigella sativa essential oil. Phytotherapy Research, 2000; 14: 323-328.

13. Maforimbo E Evaluation of capsicum as a source of natural antioxidant in preventing rancidity in sunflower oil. Journal of Food Technology in Africa, 2002; 7: 68-72.

14. Abraham G and RJ Hron Oil seeds and their oils. In: Hui YJ Ed., Encyclopedia of Food Science and Technology. John Wiley and Sons Inc. 1992. 
15. Omeje EO, Okide GB, Esimone CO and U Ajali Kinetics of autoxidation of an oil extract from Terminalia catappa. Indian Journal of Pharmaceutical Science, 2008; 70:260-262.

16. Ajayi IA and O Adesanwo Comparative study of the mineral element and fatty acid composition of dacryodes edulis pulp and seed. World Journal of Agricultural Sciences, 2009; 5: 279-283.

17. Ajayi IA, Oderinde RA, Taiwo VO and EO Agbedana Short-term toxicological evaluation of Terminalia catappa, Pentaclethra macrophylla and Calophyllum inophyllum seed oils in rats. Food Chemistry, 2007; 106: 458465 .

18. Gurr MI The Role of Fats in Human Nutrition. In: F. B. Padley and J. Podmore (Eds.) Chichester: Ellis Horwood. 1985: p.23.

19. Cherian G, Wolfe FW and JS Sim Dietary oils with added tocopherols: Effects on egg or tissue tocopherols, fatty acids, and oxidative stability. Poultry Science, 1996; 75: 423-431

20. Yoshida H, Tatsumi $\mathbf{M}$ and $\mathbf{G}$ Kajimoto Influence of fatty acids on tocopherol stability in vegetable oils during microwave heating. JAOCS. 1992; 69: $119-125$.

21. Ronald R Phytosterol: sterols, sterolins, beta-sitosterols- Health benefit? (Online). http://www.acu-cell.com/ster.htm. 2009. Accessed on 24.04.10.

22. Rossell JB, Kochhar SP and IM Jawad Chemical changes in soy oil during high temperature processing. Proceedings of Second ASA Symp. on Soyabean Processing, Antwer, 1981.

23. FAO. United Nations Food and Agricultural Organisation. Corporate Document Repository: Fats Oils in Human Nutrition. [Onlinehttp://www.fao.org/docrep.htm. 2000 Accessed on 25/08.09.

24. Kamal-Eldin A and LA Appelquist The chemistry and antioxidant properties of tocopherols and tocotrienols. Lipids, 1996; 31: 671-701.

25 Bockisch M Fats and Oils Handbook. AOCS Press, Champaign, IL. 1998.

26. Wu XJ and C Hansen Antioxidant capacity, phenolic content, polysaccharide content of Lentinus edodes grown in whey permeate-based submerged culture. Jounral of Food Science, 2008; 73: 1-8. 


ajfiand

27. Rackova L, Oblozinsky M, Kostalova D, Kettmann V and L Bezakova Free radical scavenging activity and lipoxygenase inhibition of Mahonia aquifolium extract and isoquinoline alkaloids. Journal of Inflammation, 2007; 4: 15 .

28. Ramadan MF Kroh LW and JT Morsel Radical scavenging activity of black cumin (Nigella sativa L.), coriander (Coriandrum sativum L.) and niger (Guizotia abyssinica Cass.) crude seed oils and oil fractions. Journal of Agriculture and Food Chemistry, 2003; 51: 6961-6969.

29. Conforti F, Loizzo MR, Statti GA and F Menichini Comparative radical scavenging and antidiabetic activities of methanolic extract and fractions from Achillea ligustica ALL. Biological and Pharmaceutical Bulletin, 2005; 28: 1791-1794.

30. Dionex Corporation. Extraction of oil from oil seed by Accelerated Solvent Extraction (ASE). [Online],. http://www.dionex.com 2004. Accessed on 12.01.08. 